NOTICE: this is the author's version of a work that was accepted for publication in Marine Policy. Changes resulting from the publishing process, such as editing, corrections, structural formatting, and other quality control mechanisms may not be reflected in this document. Changes may have been made to this work since it was submitted for publication. A definitive version may be found in Marine Policy (2011), doi: 10.1016/j.marpol.2011.03.007

\title{
Governing large-scale marine commons: contextual challenges in the Coral Triangle
}

\author{
Pedro Fidelman ${ }^{1 *}$, Louisa Evans ${ }^{1}$, Michael Fabinyi ${ }^{1}$, Simon Foale ${ }^{1}$, Josh Cinner ${ }^{1}$, Franciska Rosen ${ }^{2}$ \\ ${ }^{1}$ Australian Research Council Centre of Excellence for Coral Reef Studies, James Cook University, \\ Australia
}

${ }^{2}$ Stockholm Resilience Centre, Stockholm University, Sweden

\begin{abstract}
Environment and development agendas are increasingly being characterised by regional-scale initiatives. This trend is in part motivated by recognition of the need to account for global drivers of change (e.g., climate change, migration, and globalisation), the aspirations of achieving large-scale ecological goals (such as maintaining ecosystem processes), and reconciling potentially conflicting priorities in multi-use planning. However, regional-scale governance is challenging and there is little theoretical guidance or empirical evidence to suggest how it can be achieved. This paper uses the Institutional Analysis and Development framework to highlight the diverse contextual factors that challenge governance of a large-scale marine common, using an example of the Coral Triangle Initiative. The analysis points to the need for a critical, reflexive approach to the Coral Triangle Initiative if it is to effectively navigate diverse contexts and reconcile multiple objectives in the region. Recognising the heterogeneous, multi-scale and interlinked nature of large-scale marine systems is critical. Coping with contextual complexity will require innovative approaches that strive to be inclusive of varied perspectives and actors, enable and support effective collective-choice arrangements at lower levels of organisation, and organise and link diverse institutional arrangements at multiple scales. Large-scale marine governance will also involve a great deal of experimentation and regular adjustments to governance arrangements to account for the dynamic nature of regional commons.
\end{abstract}

Keywords: marine governance; regional-scale systems; common-pool resources; complexity; Coral Triangle

\footnotetext{
* Corresponding author: P Fidelman, ARC Centre of Excellence for Coral Reef Studies, James Cook University, Townsville QLD 4811, Australia. Email: pedro.fidelman@gmail.com
} 


\section{Introduction}

Sustainable development remains an elusive societal objective. In marine and coastal systems across the world we are yet to achieve convincing and durable progress in maintaining biological diversity [1], ensuring functional and productive ecosystems [2, 3], and in reaching key Millennium Development Goals [4]. Limited progress towards sustainability is often considered a failure of governance [5]. Increasingly, scholars and practitioners in the sustainability sciences are viewing one facet of this failure as an issue of scale [6], and consensus is converging around the need for multiscale action that incorporates a regional scale.

In response, the impetus for coastal and marine governance has shifted to management at larger scales, incorporating the use of models such as Seascapes, Ecoregions, Large Marine Ecosystems, and Regional Seas programmes for conservation and fisheries management, and Mega-programmes for poverty alleviation and food security. These necessitate networks of marine protected areas (MPAs), transboundary fisheries management (monitoring, control and surveillance), and largerscale integration of conservation and development objectives $[7,8]$. Several confounding factors appear to have motivated the expansion of spatial management boundaries, including i) the perception that big problems require big solutions, ii) the recognition that external drivers of change, including climate change, often overwhelm any progress made at smaller-scales, iii) a focus on issues of representation and connectivity in light of continuous and incremental pressure on ecosystems, iv) the need to connect and manage ever increasing numbers of actors in a globalised system, and $v$ ) a push for more streamlined funding schemes that can benefit from economies of scale $[7,8,9,10,11]$.

The governance of large-scale commons, or common-pool resources (CPRs), poses a number of challenges to theorists and decision-makers alike. First, large-scale CPRs are characterised by multiple and interlinked resource systems. Second, decision- and rule-making are the responsibility of a number of formal and informal political actors that operate at multiple scales and levels. Third, because CPRs often feature diverse types of goods and services, actors must negotiate over different goals in attempting to manage simultaneously for multiple uses (e.g., fisheries, biodiversity, tourism and food security). Last, the governance of large-scale CPRs is influenced by intricate sets of endogenous and exogenous forces and relationships, operating at multiple geographic scales and levels of social and political organisation $[11,12,13,14,15,16]$.

This paper uses the Institutional Analysis and Development (IAD) framework, an analytical tool for understanding the dynamics of governance systems, to examine the contextual complexity facing organisations attempting to coordinate regional-level action. We use the Coral Triangle, a region of high concern for conservation, to ground our analysis. The paper is structured as follows. First, the IAD framework and analytical approach are presented. Then the momentum gathered around regional-governance in the Coral Triangle and the Coral Triangle Initiative are described. The analysis then examines the key contextual challenges that characterise regional-scale governance and problematise some of the current approaches to management. Finally, the discussion reiterates some key lessons learned from experiences to date in environmental governance to emphasise the need for a more critical, reflexive approach to regional-scale governance. 


\section{Analytical approach}

The Institutional Analysis and Development (IAD) framework was developed by Elinor Ostrom and colleagues $[17,18,19]$ as a tool for systematising efforts to understand which approaches to management of CPRs are likely to work best in different contexts. The framework (Figure 1) suggests several possible entry points for analysis: the context, action arena (the social space where actors make decisions and take action), patterns of interactions, and outcomes (e.g., collaboration, establishment of MPAs, conflict) (for more detail on this framework please refer to $[16,20]$ ).

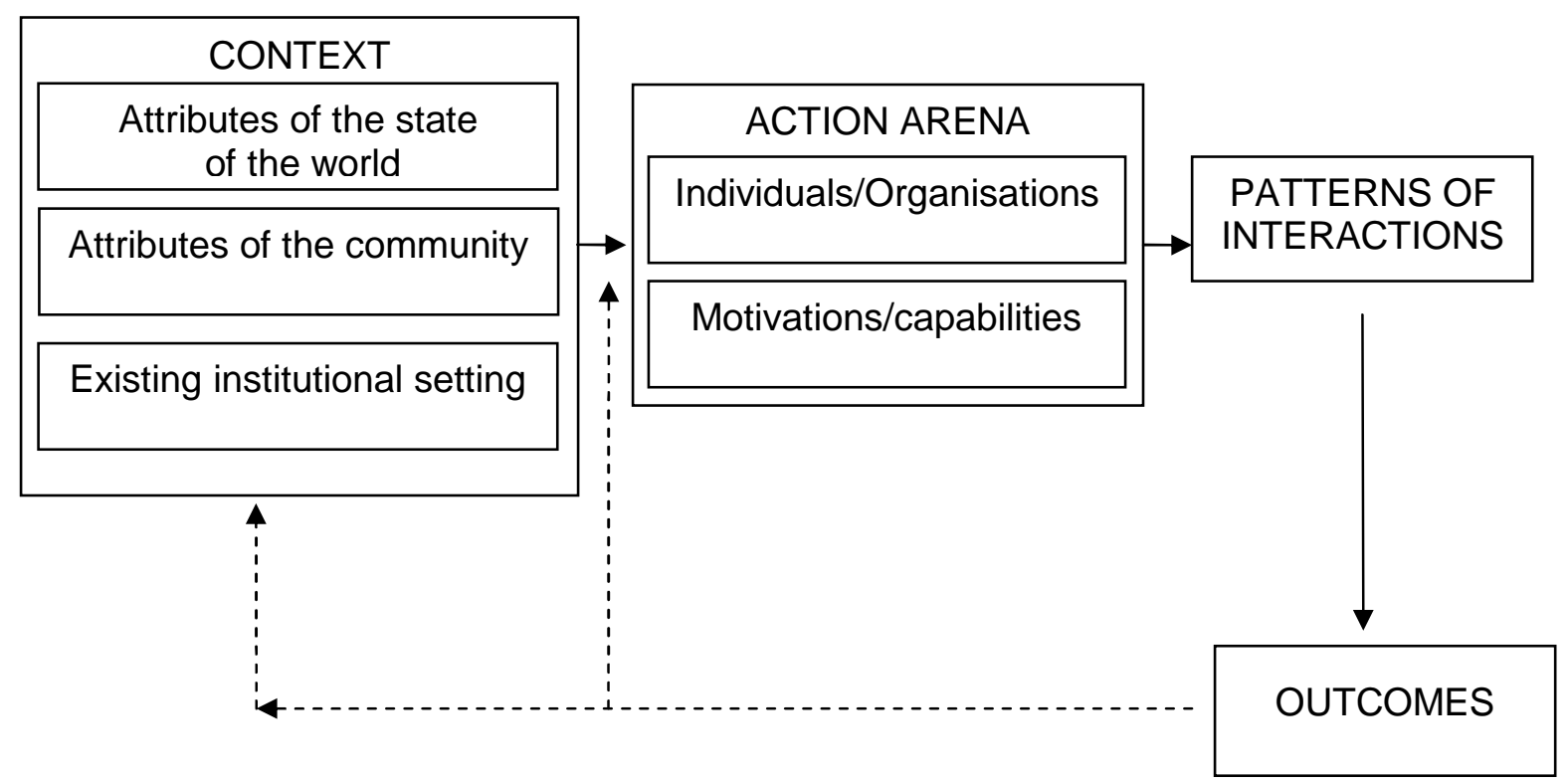

Figure 1: The IAD Framework (modified from [20]).

Given that much of the implementation of the CTI is yet to occur, the focus of analysis in this paper is on the 'context' component of the IAD. The governance choices that different stakeholders face are influenced by three broad sets of contextual factors conceptualised as: i) attributes of the state of the world, ii) attributes of the community, and iii) the existing institutional setting $[12,16,21]$. The attributes of the state of the world determine how problems are framed, what is physically possible in response to those problems, and whether the response is compatible with the underlying nature of the system being governed. The attributes of the community relate to social and cultural characteristics that might enable or constrain effective collaboration between actors. As the scale of analysis increases, the community refers to the more diverse set of stakeholders involved in regional-level action. The existing institutional setting refers to the rules, norms and strategies that guide individual and collective action. Governance of large-scale marine commons must contend with a diversity of existing institutional settings across the region. Each of these broad contextual categories has implications for the outcomes of governance, such as sustainable development. The features of the contextual factors are discussed in relation to their implications for governance of the Coral Triangle. 


\section{The Coral Triangle}

The Coral Triangle is an archipelagic region of approximately 5.7 million $\mathrm{km}^{2}$ with $153,000 \mathrm{~km}$ of coastline, which includes the seas of Indonesia (central and eastern), Malaysia (Sabah), the Philippines, Timor Leste, Papua New Guinea and the Solomon Islands [22] (Figure 2).

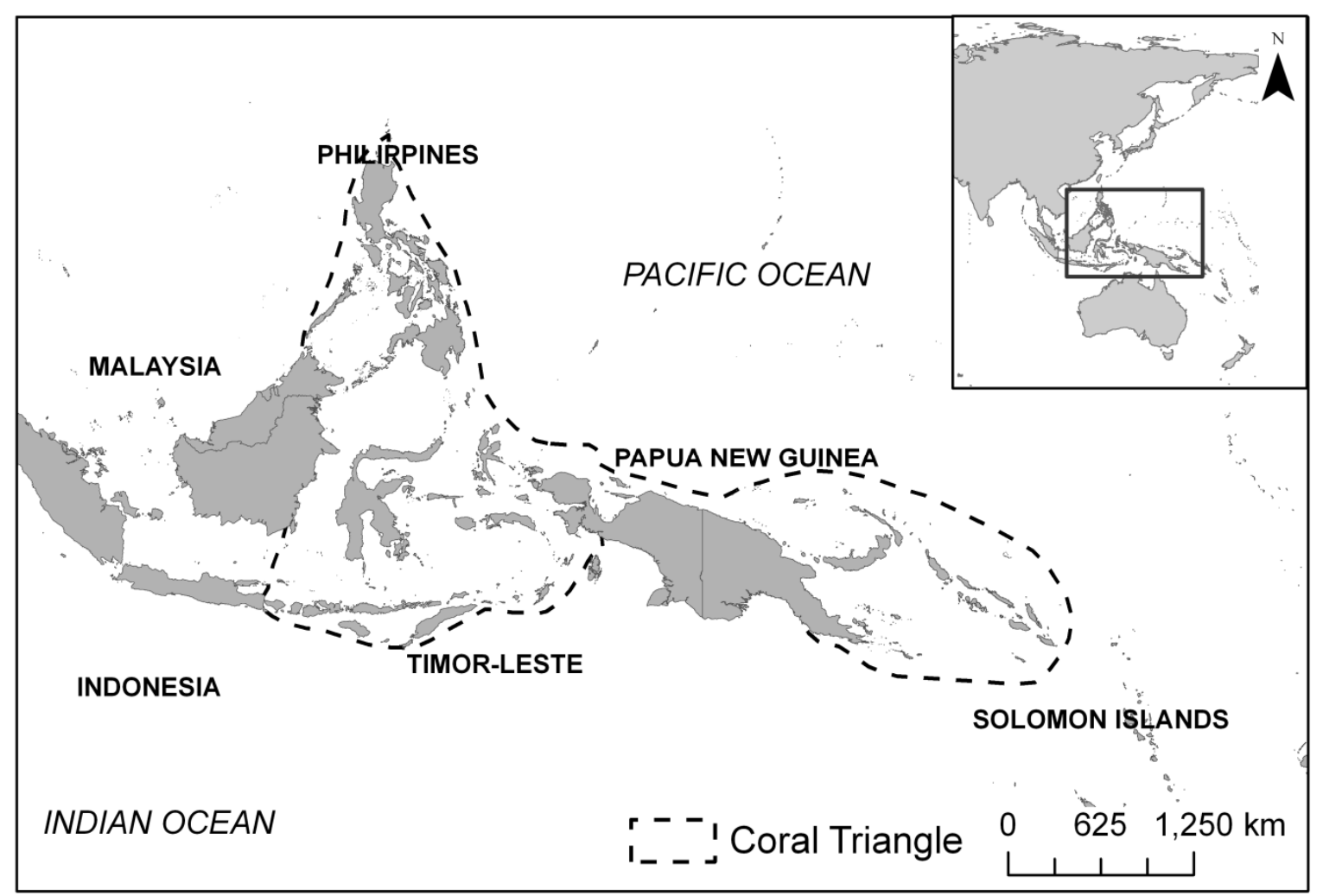

Figure 2: Map of the Coral Triangle region (after [23, 24]).

The Coral Triangle is regarded as the global epicentre of marine life biodiversity and abundance. In an effort to protect the value of this region and to pursue a more sustainable trajectory of marine resource use, the Coral Triangle Initiative on Coral Reefs, Fisheries and Food Security (CTI) has been adopted.

The CTI, an intergovernmental agreement between the countries in the Coral Triangle, was proposed by President Yudhoyono of Indonesia, and in December 2007 the governments of the six member countries agreed to develop a Regional Plan of Action "...to address threats to the marine, coastal, and small island ecosystems within the Coral Triangle region, through accelerated and collaborative action, taking into consideration multi-stakeholder participation..." [25]. The Regional Plan was adopted in May 2009 when the leaders of the six member states signed the Leaders' Declaration with support from various donors and international NGOs. Table 1 outlines the key developments in the Coral Triangle Initiative to date. 
Table 1: Development of the Coral Triangle Initiative.

\begin{tabular}{|c|c|}
\hline Date & Event \\
\hline $03 / 2006$ & $\begin{array}{l}\text { - President Yudhoyono of Indonesia highlights the critical importance of the Coral Triangle to } \\
\text { biodiversity conservation and announces his intention to enhance regional cooperation at the } \\
\text { 8th Conference of the Parties to the Convention on Biological Diversity (COP-8) in Brazil. }\end{array}$ \\
\hline 07/2007 & $\begin{array}{l}\text { - Twenty one heads of state from Asia and the Pacific welcome the CTI in their Leaders' } \\
\text { Declaration at the Asia-Pacific Economic Cooperation (APEC) Meeting in Sydney, Australia. }\end{array}$ \\
\hline $12 / 2007$ & $\begin{array}{l}\text { - The CTI is endorsed by leaders of the Association of the Southeast Asia Nations (ASEAN) as well } \\
\text { as Japan, China and Korea at the } 3^{\text {rd }} \text { East Asia Summit. }\end{array}$ \\
\hline $12 / 2007$ & $\begin{array}{l}\text { - The First Senior Officials Meeting (SOM1) is held in Bali, Indonesia in conjunction with the COP- } \\
10 \text { on Climate Change. The six Coral Triangle countries (CT6) agree to pursue the CTI and } \\
\text { develop a joint Regional Plan of Action (RPOA). A CTI Coordination Committee (CCC) is assigned } \\
\text { the task to develop the action plan. }\end{array}$ \\
\hline $12 / 2007$ & $\begin{array}{l}\text { - World Wide Fund (WWF), The Nature Conservancy (TNC) and Conservation International (CI) } \\
\text { announce an immediate commitment of funding to support consultative planning processes in } \\
\text { each country. }\end{array}$ \\
\hline $04 / 2008$ & $\begin{array}{l}\text { - The Global Environmental Facility (GEF) Council approves a US\$ } 72 \text { million, five-year CTI } \\
\text { Support Program, with over US\$300 million in co-financing from various other sources. }\end{array}$ \\
\hline $10 / 2008$ & $\begin{array}{l}\text { - The US government commits US\$ } 40 \text { million over five years to support the CTI, with funding } \\
\text { being channeled by a consortium of NGOs (WWF, TNC, CI). }\end{array}$ \\
\hline $11 / 2008$ & $\begin{array}{l}\text { - SOM2 is held in Manila, Philippines. The CT6 sign the Manila Resolution acknowledging the } \\
\text { importance of marine resources and confirming their intention to develop true partnerships. } \\
\text { Countries agree to make further revisions of the RPOA. }\end{array}$ \\
\hline $11 / 2008$ & $\begin{array}{l}\text { - The Australian government hosts a major CTI workshop in Townsville to facilitate discussions } \\
\text { by countries and NGOs on the major constraints, gaps, and opportunities to implement the CTI } \\
\text { goals. }\end{array}$ \\
\hline 01/2009 & $\begin{array}{l}\text { - CCC convenes in Manado, Indonesia to review and recommend a final draft of the RPOA. (The } \\
\text { CCC had met previously in May, September and October } 2008 \text { for the same purpose). }\end{array}$ \\
\hline $03 / 2009$ & $\begin{array}{l}\text { - SOM3 and the First Ministerial Meeting (MM1) are held in Port Moresby, Papua New Guinea. } \\
\text { The CT6 agree on a final draft of the RPOA and endorse a Ministerial Statement on the CTI. }\end{array}$ \\
\hline 05/2009 & $\begin{array}{l}\text { - The six heads of state sign the CTI Declaration and adopt the RPOA at the CTI Summit during } \\
\text { the World Ocean Congress in Manado, Indonesia. }\end{array}$ \\
\hline $10 / 2009$ & $\begin{array}{l}\text { - SOM4 is held in Kota Kinabalu, Malaysia to reach agreement on regional level coordination } \\
\text { mechanisms and the establishment of a permanent CTI Regional Secretariat. }\end{array}$ \\
\hline $11 / 2009$ & $\begin{array}{l}\text { - SOM5 is held in Honiara, Solomon Islands and continues the discussion of the previous SOM. } \\
\text { Countries agree on a CTI Roadmap for 2010-2011. }\end{array}$ \\
\hline $11 / 2009$ & $\begin{array}{l}\text { - MM2 is held in Gizo, Solomon Islands to approve and revise results from the two previous } \\
\text { SOMs. The CT6 agree on a joint ministerial statement on climate change to be presented at } \\
\text { COP-15 in Copenhagen, Denmark. }\end{array}$ \\
\hline $01 / 2010$ & $\begin{array}{l}\text { - The First CTI Business Summit is held in Manila, Philippines to facilitate private sector } \\
\text { engagement in the CTI and public-private partnerships on ocean conservation. }\end{array}$ \\
\hline $05 / 2010$ & $\begin{array}{l}\text { - A CTI Regional Priorities Workshop is convened in Jakarta, Indonesia to identify and agree on } \\
\text { regional priorities to ensure coordinated implementation of the RPOA. }\end{array}$ \\
\hline $11 / 2010$ & $\begin{array}{l}\text { - SOM6 is held in Manado, Indonesia to finalize and endorsed the Agreement to Establish the } \\
\text { Regional Secretariat. The Agreement and related documents are to be submitted for approval } \\
\text { at the Third Ministerial Meeting scheduled for early } 2011 \text {. }\end{array}$ \\
\hline
\end{tabular}

The Regional Plan of Action is a legally non-binding document setting out the core goals, targets and actions of the CTI over the next ten years (Table 2). Three of the goals primarily aspire to conservation outcomes, including the designation of priority seascapes, establishment of networks of MPAs, and the protection of threatened species. The other two goals refer to implementation of an ecosystem approach to fisheries management, under which are clustered targets on livelihoods 
and food security, and coordination of climate adaptation action. The regional plan is intended to provide an overarching framework for national level plans developed by each member country.

Table 2: Goals and targets of the Coral Triangle Initiative [49].

\section{GOAL 1: Priority Seascapes Designed and Effectively Managed}

Target 1: Priority Seascape designed, with investments plans completed and sequenced by 2012

Target 2: Marine and coastal resources within all priority seascapes sustainably managed by 2020

GOAL 2: Ecosystem Approach to Management of Fisheries (EAFM) and Other Marine Resources Fully Applied

Target 1: Strong legislative, policy and regulatory frameworks in place for achieving an ecosystem approach to fisheries management by 2012

Target 2: Income, livelihoods and food security in an increasingly significant number of coastal communities across the region improved through a new sustainable Coastal Fisheries and Poverty Reduction Initiative ("COASTFISH") by 2020

Target 3: Effective measures in place to help ensure exploitation of shared tuna stocks is sustainable, with tuna spawning areas and juvenile growth stages adequately protected by 2020

Target 4: A more effective management and more sustainable trade in live-reef fish and reef-based ornamentals achieved by 2020

GOAL 3: Marine Protected Areas (MPAs) Established and Effectively Managed

Target 1: Region-wide Coral Triangle MPA system (CTMPAs) in place and fully functional by 2020

GOAL 4: Climate Change Adaptation Measures Achieved

Target 1: Region-wide early action plan for climate change adaptation for near-shore marine and coastal environment and small island ecosystems developed by 2012 and implemented by 2015

Target 2: Networked national centres of excellence on Climate Change Adaptation for marine and coastal environments are established and in full operation by 2013

GOAL 5: Threatened Species Status Improving

Target 1: Improved status of sharks, sea turtles, seabirds, marine mammals, corals, seagrass, mangroves and other identified threatened species by 2020

The member states of the Coral Triangle and regional co-ordinating bodies will have to contend with complex contextual issues to maintaining the (considerable) momentum gathered around the CTI, and implement the regional and national plans of action. Some of the key contextual issues are examined in the next section.

\section{Contextual complexity}

\subsection{Attributes of the state of the world}

This set of contextual factors refers to the physical and material conditions of the system. These conditions affect the information available to stakeholders and how problems are framed. They influence what outcomes can be produced, so what is physically possible in response to a perceived or real problem. The physical and material conditions also determine how actions are linked to outcomes, so whether the response is compatible with the underlying nature of the system being governed $[16,26]$. In a recent adaptation of the IAD framework, Ostrom refers to attributes of the resource system and resource units [27]. Similarly, the nature of the system to be governed is identified as a key determinant of governance outcomes within the interactive governance framework developed by Kooiman et al. [28]. 
The Coral Triangle region shares a number of biophysical characteristics with implications for how the region's issues are framed and the nature of the response by the stakeholders involved in the new initiative. First, the marine, coastal and small-island ecosystems that the CTI aims to govern are comprised of CPRs. CPRs are difficult to govern because of exclusion (of users) and subtractability (extraction by one user reduces resources available to others) issues [29]. Exclusion and subtractability creates pervasive challenges to designing and implementing appropriate mechanisms to motivate responsible collective action. Such challenges are manifested in widespread examples of overexploitation in inshore coastal fisheries, as well as the prevalence of illegal, unreported and unregulated fishing (IUU) throughout the developing world [30, 31]. These issues are magnified by regional-level connections and global drivers of change. For instance, customary, local and even national institutions are typically inadequate against the growing pressures from international migrant fishing fleets [15, 32], land-use change, water quality, and large-scale pollution [33, 34]; political and environmental migration [35], and the increasing demand for international tourism [36], all of which exacerbate the issues of extraction and subtractability.

Second, fisheries and other marine commons are increasingly recognised as complex adaptive systems $[10,11,37,38]$. Complexity can arise from the sheer number of interactions that characterise these systems. So, for instance, in the Coral Triangle, complexity of this sort emerges from the range of ecosystem services provided by the region, the diversity of stakeholders involved in use, processing, trade and management of these ecosystem services, and the centrality of this region to international trade networks. Complexity is also a factor of the change dynamics of socialecological systems, which in complex adaptive systems are characterised by irreducible uncertainty, the prospect of non-linear change, and the possibility for emergence or unexpected outcomes [39]. These aspects of complexity have called into question management approaches based on reducing uncertainty, stabilising production, and preventing change [40, 41]. In many parts of the world, empirical work has demonstrated the very real prospect of phase shifts and non-linear change in marine and coastal ecosystems, including coral reefs [42], fisheries [43] and seagrass habitats [44] to less desirable configurations. In the Coral Triangle, increasingly negative effects of overfishing, climate change and coral bleaching, and pollution and coastal development on marine resources contribute to unsustainable trajectories $[33,45,46,47]$. Nevertheless, the importance of connectivity for enabling the resilience of marine systems $[9,48]$ and the high value placed on this region as an important source of ecological memory [49] seem to have considerably influenced the agenda of the CTI. The Action Plan states that "the biogeographical conditions within the Coral Triangle may enable the region to maintain its exceptional productivity in the face of future impacts of climate change, making it potentially, the world's most important 'refuge' for marine life".

Third, the Coral Triangle is a large-scale system. Common property theory identifies size and welldefined boundaries as critical factors in the success of resource governance [12, 50]. The Coral Triangle is 5.7 million $\mathrm{Km}^{2}$, the equivalent of half of the United States of America. The boundaries are well-defined but are founded on ecological criteria and do not reflect the jurisdictional or contested boundaries of the region (e.g., between Malaysia and Indonesia, see [51]). As currently defined, the Coral Triangle boundaries incorporate member nations which vary considerably in geographical scale (for instance, the Solomon Islands has a total land area of $28,369 \mathrm{~km}^{2}$ with jurisdiction over 1.34 million $\mathrm{km}^{2}$ of ocean within its 200 mile Exclusive Economic Zone, whereas Indonesia has a total area of 2 million $\mathrm{km}^{2}$ and a maritime area of 7.9 million $\mathrm{km}^{2}$ ) and incorporates different proportions of countries' national waters $[52,53,54]$. This raises questions about the proportional rights and responsibilities of CTI members, as well as the collective and individual capacities to monitor and regulate resource use in such a large geographic scale.

Last, mobility of resources, storage capacity, renewability/productivity, predictability, patchiness or spatial and temporal distribution, ecological interactions between resource units, and distinctive 
markings are other notable attributes that will influence governance [55]. In almost all instances, the nature of marine and coastal resources in regards to these attributes makes them more difficult to govern than other resources. Many marine species including pelagic fisheries, turtles, dolphins and whales are highly mobile over large distances, moving within and beyond the Coral Triangle boundaries. The major tuna fisheries (e.g., skipjack and yellow fin tuna), for example, spend parts of their life cycles in more than one Exclusive Economic Zone, as well as in the high-seas [56, 57]. The high mobility of marine resources is compounded by the unpredictable nature of many species, the spatial and temporal patchiness of migrating species, and the lack of distinctive marking on individual resources. Each of these factors erodes the incentives of marine resource users to limit exploitation and forgo immediate benefits for a future date. An obvious contrast is between wild capture fishers and pastoralists who can privately own a defined number of branded cattle and thereby plan more effectively to optimise market opportunities and ensure future livelihood security. While pastoralists are vulnerable to extreme events such as drought they are less exposed to the day-to-day uncertainties faced by those dependent on the marine environment. These physical attributes of marine resources make it more difficult to monitor stocks and flows of resources, to understand resource dynamics, and to moderate levels of resource use [12, 50]. Further, such attributes will differ across resources throughout the Coral Triangle region adding to the diversity of situations that governance must address. For instance, the Coral Triangle region contains 76 percent of the world's coral species, 37 percent of the world's reef fishes [58], as well as 73 percent of the world's mangrove species and 46 percent of the world's seagrass species [33]. While these resources provide the primary justification for governance of the region, the variance across them, let alone other ecosystem services in the region, poses a serious challenge to governance.

Indeed, often these biophysical contextual factors have contributed to the widespread failure of management of natural resources across the region. The latest Reefs at Risk report [47] documents that an estimated 95 percent of Southeast Asian reefs are threatened, with over 50 percent of these reefs being at high or very high risk. Indonesia and the Philippines possess 77 percent of Southeast Asia's reefs and 80 percent of the threatened reefs in the region, with continued human impact estimated to cost each country more than US\$ 2 billion over 20 years [33]. The Reefs at Risk Revisited report notes that the Pacific reefs are under less threat with 50 percent of reefs considered as threatened. However, many of these reefs, including those near population centres in Papua New Guinea and the Solomon Islands [47], experience considerable human pressure, which is expected to rise in the near future. It is estimated that future national demand for ecosystem services in the Pacific will outstrip supply by 2030, particularly in light of poor management [59]. The declining state of marine resources in the region is of significant concern among conservationists, scientists, governments and others. However, it is important to note that the motivation for the CTI appears to be founded more on the high biodiversity value of the region than on its level of threat or decline and the implications of this for regional development.

\subsection{Attributes of the community}

The attributes of the community (referring, here, primarily to sets of stakeholders) refer to social and cultural dimensions that constrain or enable effective collective action. These attributes comprise forms of human and social capital, such as levels of education, trust and norms of reciprocity. They also include levels of common understanding and homogeneity of preferences and interests amongst stakeholders involved in governance [19]. Common property theory suggests that devising an appropriate set of rules for governing complex CPRs is easier where stakeholders share a common set of values e.g., culture, language, norms of reciprocity and trust $[12,16]$. The reality across the Coral Triangle is that political, economic, and cultural contexts are extremely diverse and 
it is likely that these contextual factors will prove the most challenging to the CTI. Furthermore, the "community" in the Coral Triangle comprises a wide range of social and political actors including government agencies, international NGOs, development agencies and donors, resource users, community groups and research organisations. The following analysis indicates the extent to which socio-cultural and socio-economic attributes vary across the region.

Socio-cultural attributes differ across the Coral Triangle both between and within member states (Table 3). The countries in the Coral Triangle have a combined population of approximately 372 million people. Indonesia has the largest population, with over 240 million people (over 60 percent of the total for the countries in the region) and the Solomon Islands has the smallest, with approximately 0.6 million inhabitants. Population growth in the region varies between $1.1 \%$ pa for Indonesia and $2.4 \%$ pa for the Solomon Islands. Population density varies between 328 people per $\mathrm{Km}^{2}$ in the Philippines and 14 people per $\mathrm{Km}^{2}$ in Papua New Guinea [54]. These populations are themselves diverse in their make-up of ethnic groups, languages and religions (Table 3 ).

Table 3: Some socio-cultural attributes of the Coral Triangle Initiative member states [54].

\begin{tabular}{|c|c|c|c|c|c|c|}
\hline & Indonesia & Malaysia & Philippines & Timor Leste & PNG & $\begin{array}{l}\text { Solomon } \\
\text { Islands }\end{array}$ \\
\hline $\begin{array}{l}\text { Population } \\
\text { (million) }\end{array}$ & 240.3 & 25.7 & 97.9 & 1.1 & 6.1 & 0.6 \\
\hline $\begin{array}{l}\text { Population } \\
\text { Growth (\% pa) }\end{array}$ & 1.1 & 1.7 & 2.0 & 2.0 & 2.1 & 2.4 \\
\hline $\begin{array}{l}\text { Population } \\
\text { Density } \\
\left(\mathrm{ppl} / \mathrm{km}^{2}\right)\end{array}$ & 133 & 78 & 328 & 73 & 14 & 21 \\
\hline $\begin{array}{l}\text { Main ethnic } \\
\text { groups }\end{array}$ & $\begin{array}{l}\text { Javanese, } \\
\text { Sundanese }\end{array}$ & $\begin{array}{l}\text { Malay, } \\
\text { Chinese, } \\
\text { Indian }\end{array}$ & $\begin{array}{l}\text { Tagalog, } \\
\text { Cebuano, } \\
\text { llocano }\end{array}$ & $\begin{array}{l}\text { Austronesia } \\
\text { (Malayo- } \\
\text { Polynesian), } \\
\text { Papuan }\end{array}$ & Melanesian & Melanesian \\
\hline Language & $\begin{array}{l}\text { Bahasa } \\
\text { Indonesia } \\
\text { (official), local } \\
\text { dialects (e.g., } \\
\text { Javanese) }\end{array}$ & $\begin{array}{l}\text { Bahasa Malaysia } \\
\text { (official), English, } \\
\text { Chinese dialects }\end{array}$ & $\begin{array}{l}\text { Filipino and } \\
\text { English (official), } \\
\text { eight major } \\
\text { dialects }\end{array}$ & $\begin{array}{l}\text { Tetum and } \\
\text { Portuguese } \\
\text { (official), } \\
\text { Bahasa } \\
\text { Indonesia }\end{array}$ & $\begin{array}{l}\text { Tok Pisin, } \\
\text { English and Hiri } \\
\text { Motu (official), } \\
\sim 800 \\
\text { indigenous } \\
\text { languages }\end{array}$ & $\begin{array}{l}\text { Melanesian } \\
\text { pidgin (lingua } \\
\text { franca), English } \\
\text { (official), } \\
\sim 70 \text { indigenous } \\
\text { languages }\end{array}$ \\
\hline $\begin{array}{l}\text { Predominant } \\
\text { Religion }\end{array}$ & Muslim & Muslim & Catholic & Catholic & $\begin{array}{l}\text { Christian of } \\
\text { various } \\
\text { denominations }\end{array}$ & $\begin{array}{l}\text { Christian of } \\
\text { various } \\
\text { denominations }\end{array}$ \\
\hline
\end{tabular}

Divisions, tensions and violence between different social and cultural groups are characteristic of many parts of the Coral Triangle. In Indonesia, for example, years of authoritarian rule and policies (e.g., the transmigration program) altered the ethnic and religious balance in many regions generating divisions within the society, resulting in large-scale ethnic and religious violence in central and eastern Indonesia $[60,61]$ and in West Papua [62]. Likewise, tensions exist in southern Philippines between Muslims and Catholics [60]. In addition, Melanesia experiences a low level of social cohesion due to its particular social structure based on a segmentary lineage system (i.e., a model of social organisation based on a branching system of kinship descent) [63, 64]. 
In the context of marine resources, there has been increasing tension between and among different user groups in Southeast Asia (e.g., artisanal vs. commercial fishers), due to competition over declining and overexploited stocks $[65,66]$. Conflicts between various stakeholder groups arise from the marginalisation of artisanal fisheries by other forms of resource use, different perceptions among actors on the benefits and costs of conservation and tourism, and on the purpose of management initiatives (e.g., MPAs). These conflicts are characterised by misunderstandings between the needs of local user groups and the interests of tourism and conservation actors $[67,68$, $69,70]$. Interpersonal conflicts between long-standing rivals within local communities, usurpation of control by elite stakeholders, and marginalisation of local communities have, in many cases, eroded marine resources management initiatives [69].

There are also considerable economic disparities throughout the Coral Triangle. Malaysia has the highest GDP per capita (PPP) in the region (US\$14,800) while PNG and Timor Leste have the lowest (US\$ 2,400) (Table 4). Economic growth rates for 2009 vary between $7.2 \%$ pa for Timor Leste to $0.9 \%$ for the Philippines and $-2.2 \%$ pa for Malaysia. The economies of PNG and the Solomon Islands are dependent on primary industry whereas Indonesia, the Philippines and Malaysia are multi-sector based economies.

Table 4: Economic indicators of the Coral Triangle Initiative member states [54].

\begin{tabular}{|c|c|c|c|c|c|c|}
\hline & Indonesia & Malaysia & Philippines & Timor Leste & PNG & $\begin{array}{l}\text { Solomon } \\
\text { Islands }\end{array}$ \\
\hline GDP ppp (\$ billion) & 969.2 & 381.1 & 324.8 & 2.74 & 14.2 & 1.57 \\
\hline GDP per capita & 4,000 & 14,800 & 3,300 & 2,400 & 2,400 & 2,600 \\
\hline Growth rate (\%) & 4.5 & -2.2 & 0.9 & 7.2 & 4.0 & 0.4 \\
\hline \multicolumn{7}{|l|}{ GDP per sector (\%): } \\
\hline Agriculture & 15.3 & 9.4 & 14.9 & 32.2 & 33.5 & 42 \\
\hline Industry & 47.6 & 40.9 & 29.9 & 12.8 & 35.0 & 11 \\
\hline Services & 37.1 & 49.7 & 55.1 & 55 & 31.5 & 47 \\
\hline
\end{tabular}

Marine and coastal ecosystem services provide essential contributions to the national economies in these countries. It is estimated that the potential economic benefits from coral reefs in Southeast Asia range from US\$23,100 to 270,000 per $\mathrm{km}^{2}$ per year. Coral reefs of Indonesia and the Philippines, for example, are believed to provide annual economic benefits estimated at US\$ 1.6 billion and US\$ 1.1 billion, respectively [33]. The fisheries sector contributes significantly to the economies of the Coral Triangle member states. In 2004, fisheries contributed US\$ 5.47 billion to Indonesia's GDP and US\$ 2.1 billion to Malaysia's, and, in 2003, US\$ 1.8 billion to the Philippines' [45].

The marine and coastal ecosystem services of the Coral Triangle are also important for livelihoods, local income, employment and food security for over one hundred million people across the region. The fisheries sector alone supports 7.3 million jobs in Indonesia and over 2 million in the Philippines, in 2005 and 2002 respectively [45]. Nevertheless, poverty among coastal communities in the Coral Triangle is still a concern. The Poverty and Reefs report [71] suggests that between 5-20 percent of the coastal populations of many of the countries in the Coral Triangle live on less than US\$ 1 a day.

The challenge for CTI governance is to value marine ecosystem services and their important contributions to the economies and livelihoods of inhabitants of the Coral Triangle in a way that incentivises sustainable use. Markets and commercialisation of CPRs can be beneficial when they generate funds for investment in the sustenance of the resource base and institutions that regulate their use. Therefore, when linked to "global environmental values", access to external markets may help to protect CPRs [12]. In other cases, such access to external markets can create perverse incentives resulting in overexploitation of resources $[72,73,74]$. 
At present, perverse economic incentives for resource exploitation are a major driver of overexploitation in the region. Much of the economic success of CTI member states has been based on the export of valuable but under-priced natural resources leaving fewer resources for subnational development [75]. Indeed, the Asian economic crisis in the late 90s resulted in the intensification of fisheries targeting species for export (such as the live reef fish trade and lobster, shark fin, and tuna fisheries) in Indonesia. Such intensification was driven by the devaluation of the Indonesian currency - which favoured exports - and soaring prices within the country [76]. Another example is the escalating demand for live reef food fish driven by international markets. The trade is driven by demand, particularly from Hong Kong and China (together responsible for approximately $60 \%$ of the demand) [77]. It is expected that as fish populations decline in Southeast Asia, places like Papua New Guinea and the Solomon Islands will become increasingly susceptible to overexploitation and the potential use of destructive fishing practices to satisfy the high international market demand [78].

\subsection{Existing institutional setting}

Institutions are the rules, norms and strategies that guide collective action [16, 79]. They can be set out in formal documents such as policy, legislation, management plans, and local constitutions, and/or can be embedded within more informal relationships, patterns of behaviour, written and unwritten codes of conduct, traditions and knowledge systems. The ability of stakeholders to design and implement institutions for governance, including those that determine who is involved and how (collective-choice institutions), as well as those that mediate resource allocation, monitoring and enforcement (operational institutions) is considered to be an essential element of successful CPR governance $[16,50]$. The existing institutional setting, alongside the other contextual factors of attributes of the state of the world and attributes of the community mediate how legitimate and effective governance of a defined system will be. At the same time, the other contextual factors will influence how institutions are developed and implemented and whether they are effective in practice [16]. Often, governance interventions underplay the relevance of the existing institutional setting. The existing institutional setting and the legacy of historical institutional settings set the context for institutional and governance reform and innovation. Regional coordination and implementation of the CTI goals will need to contend with the myriad of existing institutional arrangements across the Coral Triangle region at the level of the broad political and legal settings in each member state (Table 5), at the level of the international and regional institutions that guide management of coastal and marine resources (Table 6), and at the level of the operational institutions for resource use and management (Table 7).

The majority of the CTI member states, with the exception in some cases of Timor Leste, are signed up to a number of international conventions covering conservation, development, climate change, trade and marine sovereignty. There are also a high number of regional agreements within Southeast Asian countries, within Pacific countries, and between the two sub-regions (Table 6). 
Table 5: The broad political and legal systems across the CTI member states [54].

\begin{tabular}{|c|c|c|c|c|c|c|}
\hline & Indonesia & Malaysia & Philippines & Timor Leste & PNG & $\begin{array}{l}\text { Solomon } \\
\text { Islands }\end{array}$ \\
\hline $\begin{array}{l}\text { Political } \\
\text { System }\end{array}$ & $\begin{array}{l}\text { Republic, } \\
\text { presidential }\end{array}$ & $\begin{array}{l}\text { Parliamentary } \\
\text { democracy, } \\
\text { constitutional } \\
\text { monarchy }\end{array}$ & $\begin{array}{l}\text { Republic, } \\
\text { presidential }\end{array}$ & $\begin{array}{l}\text { Democratic } \\
\text { republic, } \\
\text { premier- } \\
\text { presidential }\end{array}$ & $\begin{array}{l}\text { Parliamentary } \\
\text { democracy, } \\
\text { constitutional }^{(b)} \\
\text { monarchy }^{(b)}\end{array}$ & $\begin{array}{l}\text { Parliamentary } \\
\text { democracy, } \\
\text { constitutional } \\
\text { monarchy }{ }^{\text {(b) }} \text {, } \\
\text { commonwealth }\end{array}$ \\
\hline Legal System & $\begin{array}{l}\text { Roman- } \\
\text { Dutch law }\end{array}$ & $\begin{array}{l}\text { English } \\
\text { common law, } \\
\text { and Islamic } \\
\text { law }^{\text {(a) }}\end{array}$ & $\begin{array}{l}\text { Spanish and } \\
\text { Anglo- } \\
\text { American law }\end{array}$ & $\begin{array}{l}\text { Indonesian } \\
\text { law; to be } \\
\text { replaced by } \\
\text { Portuguese } \\
\text { law }\end{array}$ & $\begin{array}{l}\text { English } \\
\text { common law }\end{array}$ & $\begin{array}{l}\text { English } \\
\text { common law }\end{array}$ \\
\hline Legislature & $\begin{array}{l}\text { Upper and } \\
\text { lower } \\
\text { houses }\end{array}$ & $\begin{array}{l}\text { Bicameral } \\
\text { parliament; } \\
\text { States have } \\
\text { hereditary } \\
\text { rulers } \\
\text { (sultans) }\end{array}$ & $\begin{array}{l}\text { Bicameral } \\
\text { congress }\end{array}$ & $\begin{array}{l}\text { Unicameral } \\
\text { national } \\
\text { parliament }\end{array}$ & $\begin{array}{l}\text { Unicameral } \\
\text { national } \\
\text { parliament }\end{array}$ & $\begin{array}{l}\text { Unicameral } \\
\text { national } \\
\text { parliament }\end{array}$ \\
\hline
\end{tabular}

(a) Islamic law is applied to Muslims in matters of family law and religion; (b) the head of state is Queen Elizabeth II represented by a governor general.

The international and regional agreements for governing coastal and marine systems that apply to the Coral Triangle share a set of principles, which, led primarily by Agenda 21, include i) sustainability and the precautionary principle, ii) participation, subsidiarity and equity, iii) good governance (accountability, legitimacy, transparency), iv) concern for system linkages (ecosystem interdependencies), v) cooperation on transboundary issues, and vi) a foundation in the best available science, but also recognition of the importance of traditional knowledge and institutions.

The CTI Regional Plan of Action [49] espouses many of the principles outlined above. For instance, the guiding principles of the Regional Plan of Action states that the CTI should support peoplecentred biodiversity conservation, sustainable development, poverty reduction, and equitable benefit sharing (principle 1), should be inclusive and engage multiple stakeholders (principle 8), should recognise the transboundary nature of some important marine natural resources (principle 6), and should be based on solid science (principle 2). Some of these principles specifically address issues related to attributes of the state of the world including the challenge of governing migratory resources and large-scale drivers of change such as pollution and climate change. Also, the CTI Regional Plan of Action explicitly states that the CTI should be aligned with international and regional commitments (principle 5). The complementarity between similar international and regional institutions and CTI goals may prove enabling; though some of these existing institutions may not be effective or even in use. 
Table 6: Examples of international and regional institutions governing marine resources across the CTI. ${ }^{(a)}$

\begin{tabular}{|c|c|}
\hline Level & Arrangements \\
\hline Global & $\begin{array}{l}\text { - Agenda } 21 \text { and the Rio Declaration on Sustainable Development } \\
\text { - Convention on Biological Diversity (CBD) } \\
\text { - Millennium Development Goals (MDGs) } \\
\text { - United Nations Framework Convention on Climate Change (UNFCCC) } \\
\text { - Kyoto Protocol to the UNFCCC } \\
\text { - Convention on International Trade in Endangered Species of Wild Fauna and Flora (CITES) } \\
\text { - Convention Concerning the Protection of the World Cultural and Natural Heritage (World } \\
\text { - Heritage Convention) } \\
\text { - World Trade Organization (WTO) } \\
\text { - FAO Code of Conduct for Responsible Fisheries } \\
\text { - United Nations Fisheries Stock Agreement (FSA) } \\
\text { - Agreement for the Implementation of the Provisions of the United Nations Convention on } \\
\text { the Law of the Sea relating to the Conservation and Management of Straddling Fish Stocks } \\
\text { and Highly Migratory Fish Stocks } \\
\text { - Agreement on Port State Measures to Prevent, Deter and Eliminate illegal, Unreported, } \\
\text { and Unregulated Fishing }\end{array}$ \\
\hline Regional & $\begin{array}{l}\text { - Convention for the Protection of the Natural Resources and Environment of the South } \\
\text { - Cacific Region } \\
\text { - Convention on Conservation of Nature in the South Pacific (Apia Convention) } \\
\text { Pacific } \\
\text { - Agreement establishing the South Pacific Regional Environment Programme (SPREP) } \\
\text { - South Pacific Commission (SPC) } \\
\text { - South Pacific Forum Fisheries Agency (FFA) } \\
\text { - Western and Central Pacific Fisheries Commission (WCPFC) } \\
\text { - Palau Arrangement for the Management of the Western Pacific Purse-Seine Fishery } \\
\text { - Niue Treaty on Cooperation in Fisheries Surveillance and Law Enforcement for the South } \\
\text { Pacific Region } \\
\text { - Convention on the Conservation and Management of Highly Migratory Fish Stocks in the } \\
\text { - Western and Central Pacific Ocean } \\
\text { - Association of Southeast Asia Nations (ASEAN) } \\
\text { - Partnerships in Environmental Management for the Seas of East Asia (PEMSEA) } \\
\text { - The Tri-national Agreements on the Sulu-Sulawesi Seas Marine Ecoregion (SSME) } \\
\text { - Arafura and Timor Seas Experts Forum (ATSEF) } \\
\text { - Indian Ocean-Southeast Asian Marine Turtle Memorandum of understanding } \\
\text { - Asia-Pacific Economic Cooperation (APEC) } \\
\text { - Agreement on the Network of Aquaculture Centres in Asia and the Pacific (NACA) }\end{array}$ \\
\hline
\end{tabular}

(a) Fidelman and colleagues (unpublished results) have identified approximately 75 multilateral arrangements relevant to the governance of marine resources in the Coral Triangle.

However, there are also examples of imbalance, since the CTI pursues a diversity of objectives that may prove difficult to reconcile. This includes implementing a "people-centred" vision that promotes sustainable development, poverty reduction and food security amidst a strong concern for biodiversity [80]. The CTI focuses on the centralisation of coastal and marine governance at the regional level, whereas most of the CTI countries have instead adopted a decentralised approach e.g., Indonesia's decentralisation law (Law No. 22/1999 revised by Law No. 32/2004) and the Philippines (Local Government Code of 1991). In addition, there is a wide spread commitment in the Coral Triangle region to community-based and co-management as the primary model for coastal resource management (e.g., [53]). Reflecting this, the importance of traditional knowledge and 


\section{[Manuscript Version]}

customary marine management (e.g., [81]) are well recognised in the fisheries and marine management policies of the Coral Triangle member states.

Principles of good governance (sensu The World Bank), such as accountability, legitimacy and transparency may also prove challenging for the CTI. The analysis of these principles, drawing on Kaufmann [82] demonstrates that the quality of governance in the Coral Triangle member states varies between low and medium, with Malaysia showing the best performance for most of the indicators (Figure 3).

Finally, at the level of the operational institutions for resource use and management, Table 7 demonstrates the number and diversity of policy and legislation guiding coastal and marine management. The formal institutions outlined in these documents, in addition to the plethora of informal institutions that guide marine governance across the Coral Triangle, present an overwhelmingly intricate existing institutional setting with which the CTI must contend. Research has often demonstrated how such diversity can lead to contradictions within and between different policies and legislation, contest between de jure and de facto rules, and surprisingly, given their number, gaps and omissions in regulation [83-85]. Another common governance problem in many of the Coral Triangle countries is the failure to coordinate developmental and environmental policies, coordinate policies between central and provincial governments and between different sectoral interests at all levels [85]. 
(a) Government effectiveness

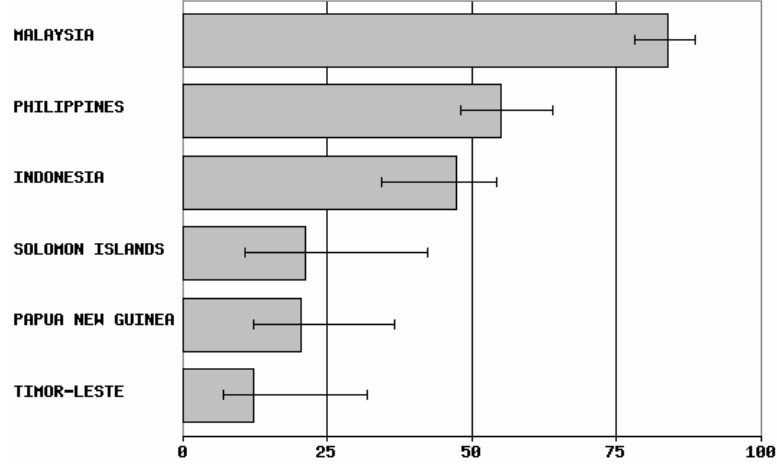

(b) Regulatory quality

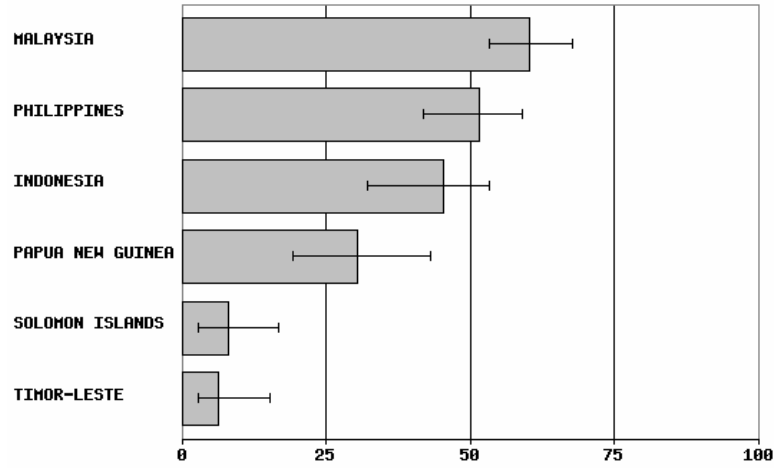

(c) Rule of law

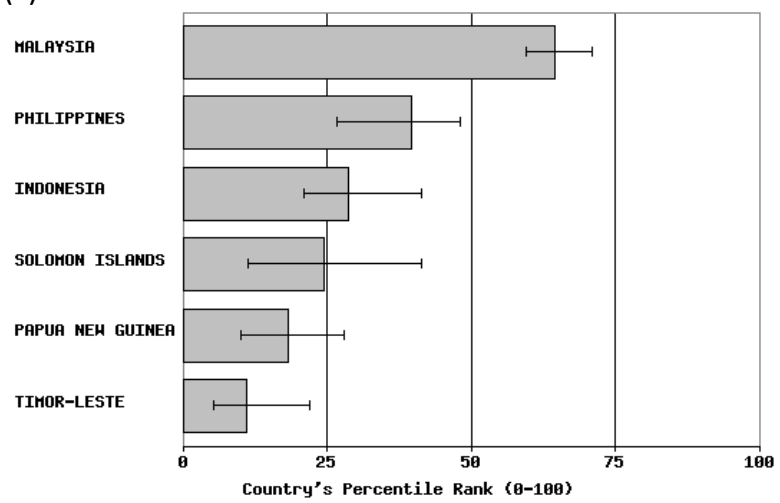

(d) Voice and accountability

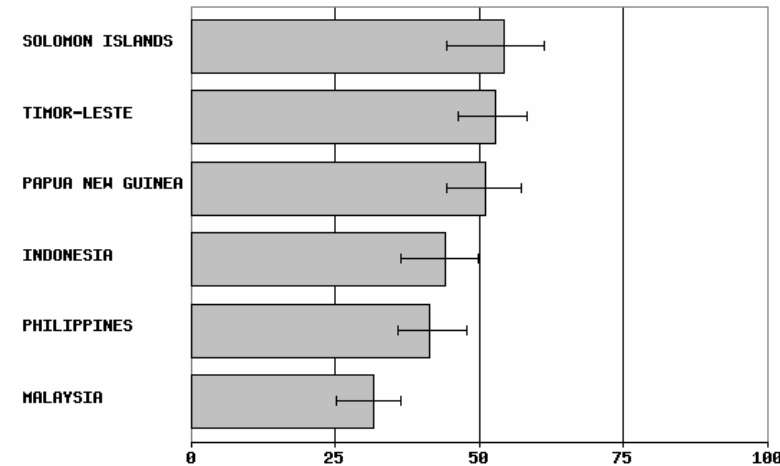

(e) Political stability

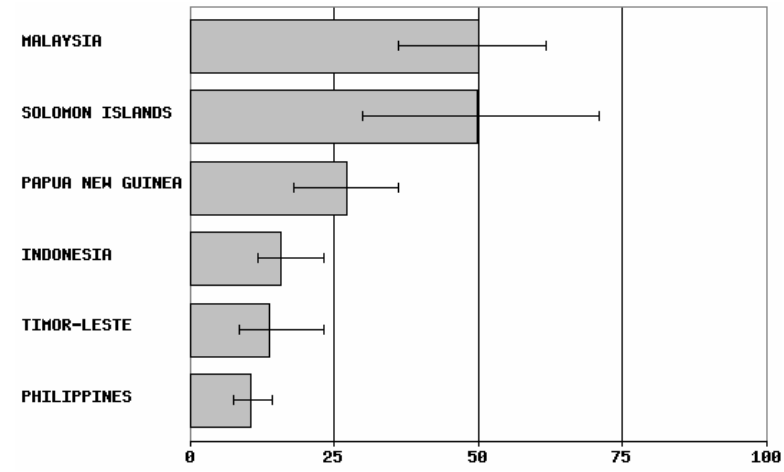

(f) Control of corruption

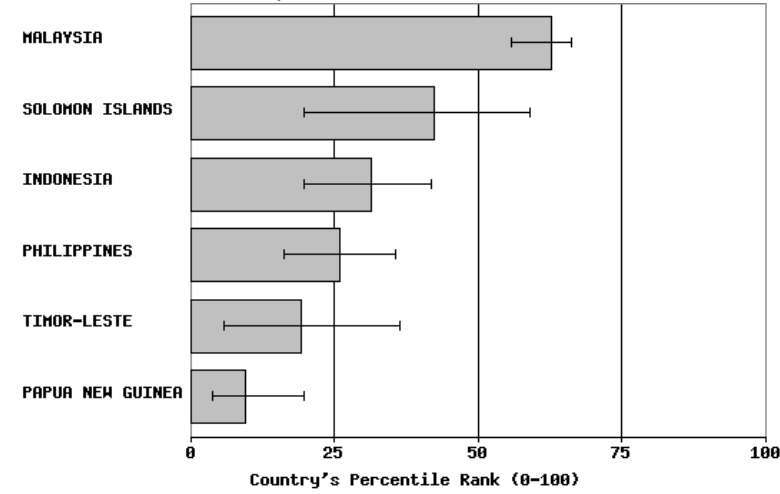

Figure 3: Indicators of governance for the Coral Triangle countries [82]. 
Table 7: Examples of national institutions for the governance of coastal and marine resources in the CTI [86].

\begin{tabular}{|c|c|}
\hline Country & Arrangement \\
\hline Indonesia & $\begin{array}{l}\text { - Environmental Management Act No.23 (1997) } \\
\text { - Fisheries Law No. } 31 / 2004 \\
\text { - Regulation No.15 regulating fishing businesses (1990, as amended) } \\
\text { - Presidential Decree No.23 regarding Sea Farming Development in Indonesian Waters } \\
\text { (1982) } \\
\text { - Law of Coastal and Small Islands Management (No. 27/2007) } \\
\text { - Law No.22/1999 on Regional Administration }\end{array}$ \\
\hline Malaysia & $\begin{array}{l}\text { - Environmental Quality Act No.127 (1974). } \\
\text { - Malaysia National Biodiversity Policy (1998) } \\
\text { - Guidelines on Erosion Control for Development Projects in the Coastal Zone (1997) } \\
\text { - Environmental Quality Order (1987) } \\
\text { - Waters Act (1920, as amended) } \\
\text { - Fisheries Act No.317 (1985) } \\
\text { - Fishermen's Associations Act (1971) } \\
\text { - Fisheries (Marine Culture Systems) Regulations (1990) }\end{array}$ \\
\hline Philippines & $\begin{array}{l}\text { - Philippine Environment Code (1988) } \\
\text { - Reorganization Act of the Department of Environment and Natural Resources (1987) } \\
\text { - Presidential Decree No. } 1586 \text { (1978) establishing an Environmental Impact Statement } \\
\text { System } \\
\text { - Marine Pollution Decree (1976) } \\
\text { - National Integrated Protected Areas System Act (1992) } \\
\text { - Philippine Fisheries Code (1998) } \\
\text { - Agriculture and Fisheries Modernization Act (1997) } \\
\text { - Fisheries Administrative Order No } 215 \text { (2001) } \\
\text { - Fisheries Office Order No. } 217 \text { (2008) } \\
\text { - Local Government Code of } 1991\end{array}$ \\
\hline Timor Leste & $\begin{array}{l}\text { - Government Decree No. 5/2004 on Fisheries } \\
\text { - Law No. } 12 / 2004 \text { on crimes related to fisheries } \\
\text { - Decree-Law No. 6/2004 on the legal regime for the management and regulation of } \\
\text { fisheries and aquaculture } \\
\text { - Regulation No. } 2000 / 19 \text { on protected places } \\
\text { - Law No. } 7 / 2002 \text { on Maritime Borders }\end{array}$ \\
\hline Papua New Guinea & $\begin{array}{l}\text { - Environment Act } 2000 \\
\text { - National Parks Regulation } 1984 \\
\text { - Fisheries Management Act } 1998 \\
\text { - Organic Law on Provincial and Local-level Governments of July } 1995 \\
\text { - Fisheries Management Regulation } 2000 \text { (No. } 2 \text { of 2000) } \\
\text { - Tuna Resources Management Act (Chapter No. 224) (1980) } \\
\text { - Declaration of Fishing Zone by the Governor-General (1978) }\end{array}$ \\
\hline Solomon Islands & $\begin{array}{l}\text { - Protected Areas Act } 2010 \text { (Act No. } 4 \text { of 2010) } \\
\text { - Environment Act, } 1998 \text { (No. } 8 \text { of 1998) } \\
\text { - Fisheries Act (1998) } \\
\text { - Fisheries Regulations (2003) } \\
\text { - Customary Land Records Act (1994) } \\
\text { - Land and Titles Act (consolidated version of 1995) }\end{array}$ \\
\hline
\end{tabular}




\section{Discussion}

This paper used the IAD framework to contextualise regional governance of the Coral Triangle. The context in which marine resources use and management take place in large-scale systems is remarkably complex. It can both enable and constrain management initiatives [87, 88]. Emergent properties of systems can only be understood in the context in which they are embedded [38]. In addition, different conservation contexts require different strategies [89]. Therefore, poor understanding of or regard for context can lead to simplified judgements about resource systems [14], and, consequently, failures in conservation efforts [69].

The Coral Triangle comprises a number of subsystems and internal variables at multiple levels [27]. The IAD framework shows that it encompasses a system with multiple action situations (i.e., loci of decision-making and action) [16]. CPRs are notoriously difficult to govern, and are increasingly so where they behave as complex adaptive systems featuring high resource mobility and low predictability over large scales. The community of stakeholders most dependent on these resources and ultimately responsible for their management has highly variable socio-cultural and socioeconomic characteristics both within and between them. Political and ethnic conflict as well as conflict over resources themselves has often defined relations in the Coral Triangle region. Heterogeneity in the governing community can enable innovation and adaptation [90]; but, can also constrain effective communication [91] and consequently collective action [16]. Designing institutions to overcome these issues is possible, but only with the understanding that CPR problems are conditioned by the context in which they are embedded.

There is cohesion and complementarity in the existing institutional landscape at the international and regional scale that can be drawn upon for the CTI. Confronting competing objectives such as biodiversity conservation and development goals (e.g., poverty reduction and food security) and regional governance and community-based management will be critical. This involves appreciating trade-offs, by which losses, costs and hard choices are openly discussed and honestly negotiated [80]. The appreciation of trade-offs may allow innovation to emerge [92]. In practice, the CTI will need to demonstrate how regional coordination and financing of governance can contend with the multitude of pressures, perspectives, and existing activities that play out at the operational scale throughout the region. In this regard it is important that some of our critical experiences and lessons accumulated to date in environmental governance are not overlooked.

The problems faced by the Coral Triangle are similar in nature to those of other complex commons. They are the cumulative result from actions taken by individuals, communities, the private sector, local, provincial/state and national governments. Solving these problems involves collaboration of individuals and organisations across scales and levels of organisation [16, 38]. Therefore, the CTI needs to be inclusive of the diversity of actors that characterise the Coral Triangle such as resource user groups, industries (e.g., fishery and tourism), community groups, scientists, local and subnational governments, and international organisations. A more inclusive approach is important to promote dialogue and collaboration around goals and outcomes. Inclusiveness is also important for the kind of (analytic) deliberation that provides for better information and assists in building social capital, resolving conflicts, coping with change and establishing linkages across scales [11,38]. For example, if divergent local and international perceptions of resource availability and sustainability are not negotiated, conflicts are expected to emerge, which can undermine the long-term viability of governance actions [10, 16, 93]. Given the large geographic scale of the Coral Triangle and the number of stakeholders involved it may not be feasible for all stakeholders to participate in decisionmaking. In this case, accountability (particularly to local populations) and legitimacy are important values in seeking to include all relevant ideas and interests in collective choice [94-96]. 
Because commons governance involves interactions at various levels of social and political organisation [16, 37, 38], large-scale institutions - though they comprise an essential part of effective governance - are not themselves a sufficient solution. These institutions need to be backed up by actions at national, provincial and local levels to work well. Therefore, coping with contextual challenges in the Coral Triangle will require institutional arrangements organised at multiple scales and linked effectively together $[10,15,16,97,98]$. It is important for the CTI to build on the existing initiatives at national and sub-national levels, as opposed to initiating an entirely new governance enterprise. For example, direct financial and technical support to some of the management initiatives already underway could essentially achieve many of the CTI goals. Furthermore, multigovernance or polycentric systems may be more effective in facilitating learning from experimentation than a single central authority $[15,16]$.

Overemphasising the regional scale as a governance solution to the Coral Triangle risks undermining institutional arrangements at sub-national and local levels [98]. Indeed, linking institutions across levels, from local to regional invokes the principle of subsidiary, by which decisions are made as close as possible to those affected by such decisions (i.e., at the lowest capable level of social organisation) [10]. The principle of subsidiarity is reflected in the decentralised policies adopted by several CTI member states. In this context, the CTI should focus on enabling and supporting effective collective-choice arrangements at lower levels of decision-making. Otherwise, it is very unlikely (if possible at all) that uniform rules established at the regional scale for the entire Coral Triangle will fit the ecological, socio-economic and political realities of the region [15, 98]. In large systems, rules are unlikely to match all aspects of the provision and appropriation of that system if designed at just one level of organisation [98].

In addition, devising improved governance in the Coral Triangle will require the deployment of a diversity of institutional types, which employ a mixture of institutional arrangements [11, 16, 99]. Therefore, coping with contextual complexities will involve the use of various governance forms such as formal government initiatives, market instruments and community self-governance. In this regard, governance needs to be understood in a broader sense to encompass as many solutions as possible for resolving conflicts over marine resources [100].

Last, in developing governance arrangements for the Coral Triangle, it is important to pay attention to power relations between the actors, how the different interests mediate those relations across levels and policy narratives that shape governance [38]. For example, marine protected area policies, particularly in less developed countries, have frequently been dictated by international nongovernmental organisations (NGOs) [101]. These policies have been incorporated into national contexts using western intellectual frameworks, which explain their generally limited relevance to local conditions [102]. The global conservation narrative of the international NGOs is very often at odds with local and national aspirations [93, 102, 103]. The top-down approaches by which international conservation initiatives are designed and implemented can also fail to recognise and incorporate the agendas of local communities, scientists, conservation practitioners and policymakers [101]. As Brosius and Russell note, by focusing on conservation at such a large scale, ecoregional initiatives (such as the CTI) have the capacity to reinforce inequities in environmental management by 'privileg[ing] large transnational conservation organisations and government agencies at the expense of grassroots or national conservation initiatives" [104: 50]. Therefore, it is critical to ensure that international conservation objectives, which are clearly manifested in the policy narratives of the $\mathrm{CTI}$, do not override important developmental goals such as food security and poverty alleviation.

In summary, governance of large-scale marine systems requires recognising the heterogeneous, multi-scale and interlinked nature of these systems. Therefore, large-scale marine commons should 
be managed simultaneously at multiple levels. Coping with contextual complexity will require innovative approaches that strive to be inclusive, organise and link institutional arrangements at multiple scales, enable and support effective collective-choice arrangements at lower levels of organisation, and employ diverse types of institutions. It will also involve a great deal of experimentation and regular adjustments to take into consideration the dynamic nature of commons governance.

\section{Acknowledgements}

Thanks to Melanie Thomas for assisting with data collection and Morena Mills for the map of the Coral Triangle. The comments on previous versions of the manuscript by Terry Hughes, Per Olsson and Chris Weible are greatly appreciated.

\section{References}

[1] Pereira HM, Leadley PW, Proença V, Alkemade R, Scharlemann JPW, Fernandez Manjarrés JF, Araújo MB, Balvanera $P$, Biggs R, Cheung WWL, Chini L, Cooper HD, Gilman EL, Guénette $S$, Hurtt GC, Huntington HP, Mace GM, Oberdorff T, Revenga C, Rodrigues P, Scholes RJ, Sumaila U R., Walpole M. Scenarios for global biodiversity in the 21st century. Science 2010; 330: 1496-1501.

[2] Hughes TP, Bellwood DR, Folke C, Steneck RS, Wilson J. New paradigms for supporting the resilience of marine ecosystems. Trends in Ecology \& Evolution 2005; 20(7): 380-386.

[3] Millennium Ecosystem Assessment. Synthesis report. Washington, DC: Island Press; 2005.

[4] Garcia SM, Rosenberg AA. Food security and marine capture fisheries: Characteristics, trends, drivers and future perspectives. Philosophical Transactions of the Royal Society B: Biological Sciences 2010; 365: 2860-2880.

[5] Acheson JM. Institutional failure in resource management. Annual Review of Anthropology 2006; 35: 117-134.

[6] Wilson JA. Matching social and ecological systems in complex ocean fisheries. Ecology and Society 2006; 11(1): 9. [online] URL: http://www.ecologyandsociety.org/vol11/iss1/art9/.

[7] Bensted-Smith R, Kirkman H. Comparison of approaches to management of large-scale marine areas. Washington, DC; Cambridge, UK: Fauna \& Flora International and Conservation International; 2010.

[8] CGIAR. Voice for change: The new CGIAR. Consultative Group on International Agricultural Research; 2010.

[9] Almany G R, Connolly S R, Heath D, Hogan JD, Jones GP, McCook LJ, Mills M, Pressey RL, Williamson DH. Connectivity, biodiversity conservation and the design of marine reserve networks for coral reefs. Coral Reefs 2009; 28: 339-351.

[10] Berkes F. From community-based resource management to complex systems: The scale issue and marine commons. Ecology and Society 2006; 11(1): 45 [online]. 
[11] Dietz T, Ostrom E, Stern PC. The struggle to govern the commons. Science 2003; 302: 19071912.

[12] Dolsak N, Ostrom E. The challenges of the commons. In: Dolsak N, Ostrom E, editors. The commons in the new millennium. Cambridge: The MIT Press; 2003.

[13] Kauneckis D, Imperial MT. Collaborative watershed governance in Lake Tahoe: An institutional analysis. International Journal of Organization Theory and Behavior 2007; 10(4): 503-546.

[14] Edwards VM, Steins NA. A framework for analysing contextual factors in common pool resources. Journal of Environmental Policy and Planning 1999; 1: 205-221.

[15] Berkes F. Linkages and multilevel systems for matching governance and ecology: Lessons from roving bandits. Bulletin of Marine Science 2010; 86(2): 235-250.

[16] Ostrom E. Understanding institutional diversity. Princeton: Princeton University Press; 2005.

[17] Ostrom E. A method of institutional analysis. In: Kauffmann F-X, Majone G, Ostrom V, editors. Guidance, control, and evaluation in the public sector. Berlin: de Gruyter; 1986.

[18] Oakerson R. Analyzing the commons: A framework. Bloomington: Workshop in Political Theory and Policy Analysis, University of Indiana; 1990.

[19] Ostrom E, Gardner R, Walker J. Rules, games, and common-pool resources. Ann Arbor: The University of Michigan Press; 1994.

[20] Ostrom E. An assessment of the institutional analysis and development framework. In: Sabatier $\mathrm{P}$, editors. Theories of the policy process (theoretical lenses on public policy). Boulder: Westview Press; 1999.

[21] Ostrom E. Copping with tragedies of the commons. Annual Review of Political Science 1999(2): 493-535.

[22] Green A, Mous PJ. Delineating the Coral Triangle, its ecoregions and functional seascapes. Version 5.0. TNC Coral Triangle Program. The Nature Conservancy; 2008.

[23] Veron JEN, DeVantier LM, Turak E. Coral geographic, online: http://www.coralreefresearch.org/html/crr_cg.htm; accessed 20/01/2011.

[24] Veron JEN, Devantier LM, Turak E, Green AL, Kininmonth S, Stafford-Smith M, Peterson N. Delineating the Coral Triangle. Galaxea, Journal of Coral Reef Studies 2009; 11: 91-100.

[25] Leaders Declaration. Coral Triangle Initiative leaders' declaration on coral reefs, fisheries and food security. Manado; 2009.

[26] Imperial MT. Institutional analysis and ecosystem-based management: The institutional analysis and development framework. Environmental Management 1999; 24(4): 449-465.

[27] Ostrom E. A general framework for analysing sustainability of social-ecological systems. Science 2009(325): 419-422. 
[28] Kooiman J, Bavinck M, Jentoft S, Pullin R, editors. For life: Interactive governance for fisheries. Amsterdam: Amsterdam University Press; 2005.

[29] Ostrom E, Burger J, Field CB, Norgaard RB, Policansky D. Revisiting the commons: Local lessons, global challenges. Science 1999; 284: 278-282.

[30] WorldBank/FAO/WorldFish. Small-scale capture fisheries: A global overview with emphasis on developing countries. A preliminary report of the Big Numbers Project; 2009.

[31] FAO. The state of world fisheries and aquaculture. Food and Agriculture Organization of the United Nations; 2008.

[32] Berkes F, Hughes TP, Steneck RS, Wilson JA, Bellwood DR, Crona B, Folke C, Gunderson LH, Leslie HM, Norberg J, Nyström M, Olsson P, Österblom H. Globalization, roving bandits, and marine resources. Science 2006; 311: 1557-1558.

[33] Burke L, Selig E, Spalding M. Reefs at risk in Southeast Asia. Washington, DC: World Resources Institute; 2002.

[34] Todd PA, Ong X, Chou LM. Impacts of pollution on marine life in Southeast Asia. Biodiversity Conservation 2010; 19: 1063-1082.

[35] Warner K. Global environmental change and migration: Governance challenges. Global Environmental Change 2010; 20: 402-413.

[36] Cheer JM. Kicking goals or offside: Is tourism development in the Pacific helping progress towards the MDGs? Pacific Economic Bulletin 2010; 25(1): 151-161.

[37] Berkes F. Commons in a multi-level world. International Journal of the Commons 2008; 2(1): 16.

[38] Armitage D. Governance and the commons in a multi-level world. International Journal of the Commons 2008; 2(1): 7-32.

[39] Norberg J, Cumming GS, editors. Complexity theory for a sustainable future. New York: Columbia University Press; 2008.

[40] Berkes F. Alternatives to conventional management: Lessons from small-scale fisheries. Environments 2003; 31: 1-14.

[41] Holling CS, Meffe GK. Command and control and the pathology of natural resource management. Conservation Biology 1996; 10(2): 328-337.

[42] Hughes TP, Graham NAJ, Jackson JBC, Mumby PJ, Steneck RS. Rising to the challenge of sustaining coral reef resilience Trends in Ecology \& Evolution 2010; 25(11): 633-642.

[43] Pennisi E. How a little fish keeps overfished ecosystem productive. Science 2010; 329: 268. 
[44] Uku J, Ndirangu S, Muthama C, Kimathi A. An evaluation of the effect of sea urchin herbivory in the Diani-Chale Lagoon. Preliminary Report no. 1, A KMFRI/CORDIO Collaborative Project; 2005.

[45] Hoegh-Guldberg O, Hoegh-Guldberg H, Veron JEN, Green A, Gomez ED, Lough J, King M, Ambariayanto A, Hansen L, Cinner J, Dews G, Russ G, Schuttenberg HZ, Panaflor EL, Eakin CM, Christensen TRL, Abbey M, Areki F, Kosaka RA, Tewfik A, Oliver J. The Coral Triangle and climate change: Ecosystems, people and societies at risk. Brisbane: World Wild Fund Australia; 2009 .

[46] Bryant D, Burke L, McManus J, Spalding M. Reefs at risk: A map-based indicator of threats to the world's coral reefs. Washington, DC: World Resources Institute; 1998.

[47] Burke L, Reytar K, Spalding M, Perry A. Reefs at risk revisited. Washington, DC: World Resources Institute; 2011.

[48] Steneck RS, Paris CB, Arnold SN, Ablan-Lagman MC, Alcala AC, Butler MJ, McCook LJ, Russ GR, Sale PF. Thinking and managing outside the box: Coalescing connectivity networks to build region-wide resilience in coral reef ecosystems. Coral Reefs 2009; 28(12): 367-378.

[49] CTI Secretariat. Regional action plan of action. Interin Regional CTI Secretariat; 2009.

[50] Ostrom E. Governing the commons: The evolution of institutions for collective action. New York: Cambridge University Press; 1990.

[51] Triggs G. Maritime boundary disputes in the South China Sea: International legal issues. Sydney: The University of Sydney; 2009.

[52] Richards AH, Bell L, Bell JD. Inshore fisheries resources of Solomon Islands. Marine Pollution Bulletin 1994; 29(1-3): 90-98.

[53] Solomon Islands Government. Solomon Islands national strategy for the management of inshore fisheries and marine resources 2010-2012. Ministry of Fisheries and Marine Resources, Solomon Islands Government; 2010.

[54] CIA. The world factbook. Central Intelligence Agency, online: https://www.cia.gov/library/publications/the-world-factbook/index.html; accessed 23/07/2010.

[55] Ostrom E. A diagnostic approach for going beyond panaceas. Proceedings of the National Academy of Science 2007; 104(39): 15181-15187.

[56] Sibert J, Hampton J. Mobility of tropical tunas and the implications for fisheries management. Marine Policy 2003; 27: 87-95.

[57] Miller KA. Climate variability and tropical tuna: Management chalenges for highly migratory fish stocks. Marine Policy 2006; 31(1): 56-70.

[58] The Nature Conservancy. Coral Triangle facts, figures, and calculations. Part II: Patterns of biodiversity and endemism. The Nature Conservancy; 2008. 
[59] Bell JD., Kronen M, Vunisea A, Warwick JN, Keeble G, Demmke A, Pontifex C, Andrefoue S. Planning the use of fish for food security in the Pacific. Marine Policy 2009; 33: 64-76.

[60] Rabasa A, Chalk P. Indonesia's transformation and the stability of Southeast Asia. RAND Corporation; 2001.

[61] Wilson C. Internal conflict in Indonesia: Causes, symthoms and sustainable resolution. Canberra: Department of the Parliamentary Library; 2001.

[62] Ballard C. The denial of traditional land rights in West Papua. Cultural Survival Quarterly 2002; 26(3).

[63] Barnes JA. African models in the New Guinea highlands. Man 1962; 62(1,2): 5-9.

[64] Fukuyama F. State building in Solomon Islands. Pacific Economic Bulletin 2008; 23(3): 18-34.

[65] Pomeroy R, Parks J, Pollnac R, Campson T, Genio E, Marlessy C, Holle E, Pido M, Nissapa A, Boromthanarat $S$, Hue NT. Fish wars: Conflict and collaboration in fisheries management in Southeast Asia. Marine Policy 2007; 31: 645-656.

[66] Salayo ND, Ahmed M, Garces L, Viswanathan K. An overview of fisheries conflicts in south and Southeast Asia: Reccommendations, challenges and directions. NAGA WorldFish Center Quaterly 2006; 29(1 \& 2): 11-20.

[67] Majanen T. Resource use conflicts in Mabini and Tingloy, the Philippines. Marine Policy 2007; 31: 480-487.

[68] Fabinyi M. Dive tourism, fishing and marine protected areas in the Calamianes Islands, Philippines. Marine Policy 2008; 32(6): 898-904.

[69] Christie P. Marine protected areas as biological successes and social failures in Southeast Asia. American Fisheries Society Simposium 2004; 42: 155-164.

[70] Foale SJ, Macintyre MA. Green fantasies: Photographic representations of biodiversity and ecotourism in the western pacific. Journal of Political Ecology 2005; 13: 1-22.

[71] Whittingham E, Campbell J, Townsley P. Poverty and reefs. Volume 1: A global overview. Paris: DFID-IMM-IOC/UNESCO; 2003.

[72] Brewer TD, Cinner JE, Green A, Pandolfi JM. Thresholds and multiple scale interaction of environment, resource use, and market proximity on reef fishery resources in the Solomon Islands. Biological Conservation 2009; 142: 1797-1807.

[73] Cinner JE, McClanahan T. Socioeconomic factors that lead to overfishing in a small-scale coral reef fishery of Papua New Guinea. Environmental Conservation 2006; 33: 73-80.

[74] Schmitt KM, Kramer DB. Road development and market access on Nicaragua's atlantic coast: Implications for household fishing and farming practices. Environmental Conservation 2010; 36(4): 277-288. 
[75] Mulekon LV, Axelsson A, Batungbacal EP, Baxter D, Siregar R, De La Torre I, SEAFish for Justice. Trade and export orientation of fisheries in Southeast Asia: Under-priced export at the expense of domestic food security and local economies. Ocean \& Coastal Management 2006; 49: 546-561.

[76] Erdmann MV, Pet JS. Krismon \& dfp: Some observations on the effects of the Asian financial crisis on destructive fishing practices in Indonesia. Live Reef Fish Information Bulletin 1999; 5 : 22-26.

[77] Sadovy YJ, Donaldson TJ, Graham TR, McGilvray F, Muldoon GJ, Phillips MJ, Rimmer MA, Smith A, Yeeting B. While stocks last: The live reef food fish trade. Manila: Asian Development Bank; 2003.

[78] Bechtel J, Werner TB, Llewewllyn G, Salm RV, Allen GR. Coral triangle. In: Glover LK, Earle SA, editors. Defying ocean's end: An agenda for action. Washington, DC: Island Press; 2004.

[79] Young OR. Science plan - institutional dimensions of global environmental change. Bonn: International Human Dimensions Programme on Global Environmentl Change, Institutional Dimensions of Global Environmental Change; 2005.

[80] McShane TO, Hirsch PD, Trung TC, Songorwa AN, Kinzig A, Monteferri B, Mutekanga D, Thang HV, Dammert JL, Pulgar-Vidal M, Welch-Devine M, Brosius JP, Coppolillo P, O'Connor S. Hard choices: Making trade-offs between biodiversity conservation and human well-being. Biological Conservation 2011; 144(3): 966-972.

[81] Cinner JE, Aswani S. Integrating customary management into marine conservation. Biological Conservation 2007; 140: 201-216.

[82] Kaufmann D, Kraay A, Mastruzzi M. Governance matters VIII: Aggregate and individual governance indicators, 1996-2008. Washington, DC: The World Bank; 2009.

[83] Dirhamsyah D. Indonesia legislative framework for coastal resource management: A critical review and recommendation. Ocean \& Coastal Management 2006; 49: 68-92.

[84] Idrus MR. Hard habitats to break: Investigating coastal resource utilisation and management in Sulawesi, Indonesia. University of Canterbury, PhD Thesis; 2009.

[85] Tan AKJ. Environmental laws and institutions in Southeast Asia: A review of recent developments. Singapore Yearbook of International Law 2004; VIII: 177-192.

[86] ECOLEX. Information service on environmental law. FAO, IUCN, UNEP, online: www.ecolex.org; accessed 15/12/2010.

[87] Pollnac R, Christie P, Cinner J, Dalton T, Daw T, Forrester G, Graham N, McClanahan T. Marine reserves as linked social-ecological systems. Proceedings of the National Academy of Science 2010; 107(43): 18262-18265.

[88] Cinner J, McClanahan T, Daw T, Graham NAJ, Maina J, Wilson SK, Hughes TP. Linking social and ecological systems to sustain coral reef fisheries. Current Biology 2009; 19: 206-212. 
[89] Robinson JG. Ethical pluralism, pragmatism, and sustainability in conservation practice. Biological Conservation 2011; 144(3): 958-965.

[90] Bodin O, Crona BI. The role of social networks in natural resource governance: What relational patterns make a difference? Global Environmental Change 2009; 19(3): 366-374.

[91] Adams WM, Brockington D, Dyson J, Vira B. Managing tragedies: Understanding conflict over common pool resources. Science 2003; 302: 1915-1916.

[92] Cortner HJ, Moote MA. The politics of ecosystem management. Washington, DC: Island Press; 1999.

[93] Agardy T. Global marine conservation policy versus site-level implementation: The mismatch of scale and its implications. Marine Ecology Progress Series 2005; 300: 242-248.

[94] Trachtenberg Z, Focht W. Legitimacy and watershed collaborations. The role of public participation. In: Sabatier P, Focht W, Lubell M, Trachtenberg Z, Vedlitz A, Matlock M, editors. Swimming upstream: Collaboratives approaches to watershed management. Cambridge: MIT Press; 2005.

[95] Ribot JC. Choosing representation: Institutions and powers for decentralized natural resource management. Interlaken, Switzerland; 2004.

[96] Bene C, Belal E, Baba MO, Ovie S, Raji A, Malasha I, Njaya F, Andi MN, Russell A, Neiland A. Power struggle, dispute and alliance over local resources: Analyzing 'democratic' decentralization of natural resources through the lenses of Africa inland fisheries. World Development 2009; 37(1935-1950).

[97] Ostrom E. Polycentric systems for coping with collective action and global environmental change. Global Environmental Change 2010; 20(4): 550-557.

[98] Ostrom E. Designing complexity to govern complexity. In: Hanna S, Munasinghe M, editors. Property rights and the environment: Social and ecological issues. Washingyon, DC: The Beijer International Institute of Ecological Economics and The World Bank; 1995.

[99] Dietz T, Dolsak N, Ostrom E, Stern PC. The drama of the commons. In: Ostrom E, Dietz T, Dolsak N, Stern P C, Stovich S, Weber E V, editors. The drama of the commons. Washington, DC: National Academy Press; 2002.

[100] Paavola J. Institutions and environmental governance: A reconceptualization. Ecological Economics 2007; 63: 93-103.

[101] Rodríguez JP, Taber AB, Daszak P, Sukumar R, Padua S, Aguirre LF, Medellín RA, Acosta M, Aguirre AA, Bonacic C, Bordino $P$, Bruschini J, Buchori D, González $S$, Mathew T, Méndez $M$, Mugica L, Pacheco L, Dobson AP, Pearl M. Globalization of conservation : A view from the south. Science 2007; 317(5839): 755-756.

[102] Pajaro MG, Mulrennan ME, Vincent ACJ. Toward an integrated marine protected areas policy: Connecting the global to the local. Environment, Development and Sustainability 2010; 12(6): 945-965. 
[103] Foale SJ. Where's our development?' landowner aspirations and environmentalist agendas in western solomon islands. The Asia Pacific Journal of Anthropology 2001; 2(2): 44-66.

[104] Brosius JP, Russell D. Conservation from above: An anthropological perspective on transboundary protected areas and ecoregional planning. Journal of Sustainable Forestry 2003; 17(1): 39-65. 